anastigmat $f 1 \cdot 8$ ) and the film is a small slab of glass which rotates about an axis parallel to its own plane and passing through the middle of the slab. This gives a lateral motion to the image in the same direction as that in which the film is moving. Exposure is only allowed when the slab is approximately normal to the optic axis, when the lateral speed of the image will be $\omega T(\mu-1) / \mu$, where $T$ is the thickness of the slab and $\omega$ its angular velocity. There is no mechanical shutter other than the mounting of the slab, which intercepts the light twice for every complete revolution, and this combined motion of film and image takes the place of the more usual motion hitherto adopted. The image of a moving dial is projected on to the corner of each exposure by an accessory internal optical system. The motion of the dial is controlled independently by a 200 -fork controlling a synchronous motor. The time spacing on the image can be read to $\frac{1}{1000}$ sec. The demonstrations of muscular reaction times and of splashes were extremely good, but it was noticed that in the com. paratively simple image of a falling steel ball, there was a slight elongation.

\section{International Broadcasting Union}

TuE International Broadcasting Union (or the Union Internationale de Radiodiffusion-to use its official title) is making its first official visit to Great Britain at the meeting which is being held in London from June 12 until June 20. The issue of World Radio of June 8 contains a series of articles describing the organisation and work of the Union. When the Union was founded in London in March 1925, eight European countries were represented, and according to the minutes of that meeting it was estimated that the broadcasting stations in Europe at that moment radiated a total energy of 80 kilowatts, of which 43 kilowatts emanated from stations in Great Britain. At the present time, in the tenth year of the Union's existence, twenty-five countries have members within the Union and the radiated energy of more than 250 stations included within what is officially recognised as the European zone is about 4,250 kilowatts. The particular function of the Union with which the listening public is probably most familiar is that of 'policing the ether'-in other words, maintaining the wave-lengths of stations so far as possible uninterrupted by those of other stations.

Tyis, however, is only one of many useful and essential duties performed by the Union with the aid of commissions dealing with legal, programme, relay and technical matters. In the course of its work, a spirit of co-operation has been established among the European broadcasting authorities as a result of their common membership of the Union, and in addition strong and valuable links have been forged with the broadcasting organisations of other continents, notably the great American chains and the corporation which controls Japanese broadcasting. Moreover, the Union has striven throughout its existence to promote that good understanding between nations, which is one of broadcasting's most valuable contributions to national life. Since the inception of the Union, the president of the Council has been Sir Charles Carpendale, one of the controllers of the B.B.C., while Mr. A. R. Burrows, a pioneer of British broadcasting, has filled the post of secretary-general in a popular and efficient manner at the Geneva office of the Union.

\section{British Antarctic Expedition}

Some further details of Mr. J. R. Rymill's forthcoming antaretic expedition are published in the Geographical Journal of June. It is hoped to leave Great Britain early in September in the Penola, a three-masted topsail schooner of about 200 tons with a length of $112 \mathrm{ft}$. The Penola, which is fitted with a 100 H.P. Diesel engine, was built in 1908; she is of oak, and is now being reconditioned and sheathed with greenheart at Southampton. A De Haviland Puss Moth aeroplane, capable of carrying three men, or two men with a survey camera, is being taken. Sixty dogs from West Greenland and twelve sledges will be carried. Messrs. Hampton and Stephenson, with the dogs and much of the equipment, will leave for the Falkland Islands in July, and Mr. Rymill with the rest of the expedition sailing in the Penola will meet them there in October. Discovery $I I$ is to assist in the transport of stores as far as Deception Island. Beyond that, the plans of the expedition will depend on the state of the ice, but it is hoped to set up the base house on Hearst Land in order to explore east and west by sledge. It may, however, be necessary for the ship to return to Deception Island if no good harbour is found in the far south. The expedition proposes to return to England in May 1937.

\section{Jubilee of the Society of Dyers and Colourists}

Commemorating the foundation, fifty years ago, of the Society of Dyers and Colourists, a jubilee issue of the Society's Journal has recently been published. Of the twenty-two articles which it contains, some are reviews of the advances which have been achieved during that time, and others deal chiefly with the present state of knowledge in various departments of the science and art of dyeing. A foreword is contributed by Prof. G. T. Morgan who, as an active worker in dye chemistry and as president of the oldest chemical society in the world, refers to the rise of the British colour industry and to the means whereby Parliament has safeguarded its growth. Mr. J. Huebner contributes an interesting account of the early history of dyeing, and Mr. A. H. Brewin sketches the history of the Worshipful Company of Dyers, London. Prof. A. G. Green discusses landmarks in the evolution of the dyestuff industry during the past half-century, and Dr. H. Levinstein contributes some pertinent observations on British patent laws. Articles on the constitution of cellulose by Prof. W. N. Haworth, on substitution in the benzene nucleus by Prof. R. Robinson, and on the relation between the constitution and substantivity of dyes by Prof. P. Ruggli serve as a reminder, should any be necessary, of the close dependence of a successful chemical industry on researches in 'pure' chemistry. Among the other articles, no less interesting because 
of a technical character, are accounts of progress in various dyeing, cleaning, bleaching and finishing operations applied to textiles, furs and leather, and a review of the chemistry and technology of rubber and synthetic resins. The price of the special issue is 25s., but members of the Society may purchase one copy at a privilege price.

\section{The National Physical Laboratory}

THE report of the National Physical Laboratory for the year 1933 is a quarto pamphlet of 264 pages and 50 figures, many of them plates, and provided with an index of 10 pages. The condition of industry has reduced the demand for routine tests of instruments and for investigation of problems of manufacture, but the research programmes of the Executive Committee and of the Boards and Committees of the Department of Scientific and Industrial Research have been pressed forward. An important and promising method of bringing provincial industries into touch with the Laboratory has been tried during the year, by the senior members of the staff lecturing on the general work of the Laboratory and on specific problems of local industries at many large towns in the country. Each department of the Laboratory provides its report, and each report contains matter of great interest which is well illustrated by figures and easily followed. The Radiology Division has, for example, investigated the effect of heat treatment on metals which have been cold-worked previously, and finds that a magnet steel retains its magnetic properties better when in a state of strain than when the strain is relieved by heat treatment, and that transformer steel is the better for being free from internal strain. On one hand, the Department has tested for internal flaws two Diesel engine connecting rods of 4-in. diameter, and on the other, for the Medical Research Council, the structure of human teeth.

\section{Quieter Motor-Cars}

A RECENT report by Science Service gives a resume of the discussions during the annual general meeting of the Society of Automotive Engineers at Detroit. It was stated that in the earlier days of motoring the thrill of passing another motorist was incomplete unless your motor had a louder and deeper roar than his. Now motorists are worried even by the amount of noise their tyres make. Modern car mechanisms are so improved that at speeds below 40 miles an hour this noise is clearly audible. In fact some motorists utilise it to keep the speed constant. The low buzz or flutter is due to the trapping of air in parts of the tyres. Noise in motor-cars can be eliminated in two ways. either by absorption or cancellation by interference. In mufflers which absorb sound, the sound energy is converted into heat by resonators owing to the friction of waves passing through small holes and the use of porous materials. Mufflers that depend on wave interference get one part of the sound in opposition in phase with the other, so that they partially cancel. One new type of muffler passes part of the exhaust gas through a venturi tube and it then operates the windshield cleaner. A silencer which utilises both resonance chambers and absorbing materials is sometimes effective in preventing intake noise (power roar). The noise to passengers can be considerably reduced by padding the bodies of the saloon by sound absorbing material in the same way as the acoustical properties of radio studios can be improved. One result of making motor-cars quieter is that the driver often unconsciously increases the speed.

\section{Venereal Disease in Literature}

Is a paper on this subject read on May 30 before the Medical Society for the Study of Venereal Diseases, Dr. J. D. Rolleston said that in no department of medicine is a knowledge of the lay writers on the history of the subject more necessary than in the domain of venereal disease. The information furnished by poets, dramatists, novelists and historians forms a valuable supplement to that derived from the study of contemporary medical works. In a survey of non-medical literature from the earliest times down to the present day containing any references to the three principal venereal diseases, Dr. Rolleston came to the following conclusions. There is no definite evidence that syphilis existed in Biblical times, classical antiquity or the Middle Ages. In striking contrast with the absence of any certain reference to the existence of syphilis in Europe before 1495, an immense amount of literature, lay as well as medical, dealing with the new disease followed that date. On the other hand, gonorrhœea, of which the first description is in Leviticus, dates from remote antiquity, but for about 250 years was identified with syphilis, the popular monosyllables for the two diseases being applied indiscriminately in lay literature to syphilis or gonorrhœa. Chancroid was probably as old as gonorrhoea and was well known in classical antiquity and the Middle Ages.

\section{Human Sterilisation}

The April number of the Eugenics Review is largely devoted to the subject of sterilisation. Major Leonard Darwin makes a detailed analysis of the report of the Departmental Committee known as the Brock Report, Dr. E. Mapother discusses the necessary safeguards in eugenic sterilisation and Prof. Hans Maier of Zurich contributes an article on practical experience of sterilisation in Switzerland, where it has been practised in certain cantons under medical supervision for more than fifty years. The legal aspects of sterilisation in Great Britain are discussed by Mr. Cecil Binney, and Dr. C. C. Hurst contributes a paper on the genetics of intellect. An account is also given of discussions in the House of Commons, and the speech of Mr. Hugh Molson, M.P., in moving that H.M. Government give immediate consideration to the recommendations made unanimously by the Committee is reproduced in full. In all cases, emphasis is laid upon the need that sterilisation should be voluntary, and with proper safeguards, as any element of compulsion defeats its own ends. 